\title{
Physical fitness and selected parameters of the respiratory system and other somatic components among 12-year-old children
}

\author{
Authors' Contribution: \\ A - Study Design \\ B - Data Collection \\ C - Statistical Analysis \\ D - Data Interpretation \\ E - Manuscript Preparation \\ $F$ - Literature Search \\ $G$ - Funds Collection \\ Marcin Pasek ${ }^{(A B C D E F G)}$, Janusz Jerzemowski ${ }^{(A D E F)}$ \\ Gdansk University of Physical Education and Sport in Gdansk, Poland
}

Key words: biological development, motor fitness, ventilation parameters, schoolchildren

\begin{tabular}{c} 
Background: \\
Material/Methods: \\
Results: \\
$\begin{array}{l}\text { The purpose of the study was to present components of fitness and body composition } \\
\text { and to determine the correlation between parameters of biological development in } \\
\text { a group of schoolchildren. }\end{array}$ \\
$\begin{array}{l}\text { Analysis of somatic features of 12-year-old children, of both sexes, from the Pomera- } \\
\text { nian province in Poland (99 boys and } 96 \text { girls) included basic parameters of the respi- } \\
\text { ratory system, body fat, height and body weight. Functional indicators, i.e. compo- } \\
\text { nents of motor abilities, have been tested. } \\
\text { Boys had significantly better results of endurance and jumping ability, and girls domi- } \\
\text { nated in flexibility and somatic components like height, weight and skinfold thickness } \\
\text { and additionally in Forced Vital Capacity and Forced Expiratory Volume in One Sec- } \\
\text { ond. In the group of boys the Maximal Mid Expiratory Flow } 25 / 75 \text { was significantly corre- } \\
\text { lated with shoulders strength. In the group of girls Forced Expiratory Volume in One } \\
\text { Second and its relationship to Forced Vital Capacity was correlated with shoulders } \\
\text { strength. The Peak Expiratory Flow rate was significantly correlated with abdominal } \\
\text { strength and flexibility. Forced Vital Capacity was correlated with flexibility and Forced } \\
\text { Expiratory Volume in One Second - with flexibility too. The biggest intensity of corre- } \\
\text { lation was observed in the case of boys skinfold thickness with speed, jumping ability, } \\
\text { shoulder strength, agility and endurance. The group of girls has weight correlated with } \\
\text { speed and jumping ability and skinfold thickness correlated with the same parame- } \\
\text { ters. Boys' endurance of was significantly correlated with weight and skinfold thick- } \\
\text { ness and girls' endurance additionally with height. } \\
\text { Significant differences between males and females have been identified with regard } \\
\text { to body type and fitness. In the group of girls more correlations between parameters } \\
\text { of the respiratory system and basic components of fitness were observed. However, } \\
\text { the opposite situation appeared in the case of relationships between the remaining } \\
\text { somatic indicators (height, weight and skinfold thickness) and general components of } \\
\text { fitness, where more correlations in the group of boys have been reported. }\end{array}$ \\
\hline
\end{tabular}

Word count: 2,295

Tables: 5

Received: February 2012

Figures: 0

Accepted: April 2013

References: 30

Published: June 2013

Corresponding author:

Dr Marcin Pasek

Gdansk University of Physical Education and Sport, Dep. of Biology, Ecology and Sports Medicine

80-336 Gdańsk, Poland, ul. K. Górskiego 1

Phone: +4858 554-73-92

E-mail: mpasek@awf.gda.pl 


\section{Introduction}

The issue of somatic conditioning of physical fitness has been a topic of numerous dissertations in the scope of biomedical studies. Polish authors [1,2] analysed the influence of height and body weight on power and speed. Similar problems were investigated by foreign authors $[3,4,5,6,7]$. That regularly practiced physical exercises are beneficial for morphofunctional parameters of the organism is a frequently and repeatedly confirmed conclusion.However, an opposite phenomenon also seems to be logical. Thus it is possible to recognize the fitness level as the outcome of the selected features of body build. Most important are, without any doubt, height and body weight as well as thickness of the fatty tissue and ventilation parameters of the respiratory system. With reference to the latter the relationship between the somatic and motor development and functions of the respiratory system is much less recognized $[8,9,10,11]$. However, it is difficult to decide which direction of these relations is stronger because physical activity influences a reduction in the fatty tissue and an increase in vital capacity to a similar degree $[12,13,14,15]$ as the features of the body composition determining the level of physical fitness and becoming a basis in sports selection [16].

The primary purpose of this study was to present components of fitness, somatic features and ventilation parameters and to determinethe correlation between selected somatic and functional components and motor skills in the group of 12-year-old children of both sexes.

\section{Material and methods}

One hundred ninety-five adolescents finishing the $5^{\text {th }}$ grade of primary school were subject to the research. Mean age for boys was 12.06; $S D=0.26$ years and for girls 12.04 ; $S D=0.29$ years. A total of 99 boys from the Pomeranian province attended two schools in the urban area (Gdynia) and two in the rural one (Choczewo, Luzino). The same schools were represented by 96 girls.

Basic anthropometric measurements were applied in the research: body height and weight as well as skinfold estimation methods based on Lohmann [17] skinfold measurement, whereby a pinch of skin is precisely measured by callipers at two standardized points on the body to determine the subcutaneous skinfold thickness (triceps and gastrocnemius in $\mathrm{mm}$ ). Medical scales, type WL-150 with stadiometer, Accu-Measure Fitness 3000 Personal Body Fat Tester were applied to measure the development of somatic features.

Selected parameters of the respiratory system: FVC (Forced Vital Capacity) and FEV1 (Forced Expiratory Volume in One Second), the ratio of FEV1 to FVC (the Tiffeneau index), MMEF $_{25 / 75}$ (Maximal Mid Expiratory Flow between 75 and 25\% of FVC) and the Peak Expiratory Flow - PEF were characterized as per protocol of execution. The multifunctional KoKo Pneumotach Spirometer was applied to measure these ventilation parameters. Measurement of physical fitness concerned basic motor abilities: speed (50-meter sprint measured correct to $0.1 \mathrm{sec}$.), jumping ability (standing long jump measured correct to $1 \mathrm{~cm}$ ), shoulders strength (pull-ups), agility (10-meter shuttle run measured correct to $0.1 \mathrm{sec}$.), abdominal strength $(30-$ second sit-up measured correct to $0.1 \mathrm{sec}$.), flexibility (trunk flexion measured correct to $1 \mathrm{~cm}$ ), tested with the International Physical Fitness Test and endurance (measured with the Cooper test correct to $10 \mathrm{~m}$ ) [18]. All results have been converted into points according to the Polish proposal for International Physical Fitness Test [19], with exception of the endurance test.

For statistical analysis (Person correlation coefficient, arithmetic mean standard deviation) the Statistica 9 software was applied. For all analyses, significance was accepted at $p \leq 0.05$. Examinations were carried out in spring of 2008.

\section{Results}

Basic results characterizing the subjects' fitness, somatic features and ventilation parameters are presented in Table 1. 
Table 1. Elementary indicators of biological development in the groups of boys and girls

\begin{tabular}{|c|c|c|c|c|c|c|c|c|c|c|}
\hline \multirow{2}{*}{ Parameter } & \multicolumn{4}{|c|}{ Boys } & \multicolumn{4}{|c|}{ Girls } & \multicolumn{2}{|c|}{$\begin{array}{l}\text { Significance of } \\
\text { difference }\end{array}$} \\
\hline & $\bar{x}$ & SD & $\max$ & $\min$ & $\bar{x}$ & SD & $\max$ & $\min$ & $t$ & $p$ \\
\hline 50-meter sprint (points) & 44.3 & 14.3 & 68 & 0 & 45.7 & 11.4 & 66 & 0 & -0.70 & 0.48 \\
\hline Standing long jump (points) & 42.7 & 10.3 & 71 & 1 & 37.1 & 14.6 & 65 & 0 & 3.09 & 0.00 \\
\hline Pull-up (points) & 42.9 & 12.5 & 79 & 0 & 45.5 & 7.6 & 73 & 0 & -1.76 & 0.08 \\
\hline 10-meter shuttle run (points) & 52.9 & 8.1 & 67 & 31 & 54.8 & 8.8 & 77 & 26 & -1.56 & 0.12 \\
\hline 30-second sit-up (points) & 54.9 & 9.7 & 95 & 32 & 53.1 & 11.0 & 98 & 12 & 1.17 & 0.24 \\
\hline Trunk flexion (points) & 45.4 & 11.5 & 69 & 1 & 50.4 & 12.4 & 74 & 6 & -2.89 & 0.00 \\
\hline Cooper test $(\mathrm{m})$ & 1980 & 339 & 2620 & 1230 & 1766 & 268 & 2240 & 1200 & 4.87 & 0.00 \\
\hline Height $(\mathrm{cm})$ & 151.0 & 8.4 & 178 & 134 & 157.0 & 8.1 & 175 & 125 & -5.03 & 0.00 \\
\hline Weight (kg) & 43.0 & 9.9 & 83 & 29 & 50.4 & 12.7 & 88 & 29 & -4.54 & 0.00 \\
\hline $\begin{array}{l}\text { Sum of triceps and gastrocne- } \\
\text { mius skinfold thickness (mm) }\end{array}$ & 29.2 & 12.3 & 67 & 12 & 34.0 & 13.6 & 68 & 12 & -2.57 & 0.01 \\
\hline FVC (I) & 2.93 & 0.46 & 4.30 & 1.98 & 3.13 & 0.57 & 5.08 & 2.04 & -2.83 & 0.00 \\
\hline FEV1 (I) & 2.60 & 0.39 & 4.06 & 1.83 & 2.80 & 0.49 & 4.40 & 1.35 & -3.25 & 0.00 \\
\hline FEV1/FVC & 0.89 & 0.05 & 1.04 & 0.73 & 0.90 & 0.06 & 1.00 & 0.65 & -1.17 & 0.24 \\
\hline $\mathrm{MMEF}_{25 / 75}(\mathrm{I})$ & 3.05 & 0.65 & 4.88 & 1.64 & 3.36 & 0.76 & 5.77 & 1.08 & -3.19 & 0.00 \\
\hline PEF (I) & 4.65 & 0.98 & 6.88 & 2.33 & 4.86 & 1.15 & 7.34 & 2.38 & -1.46 & 0.14 \\
\hline
\end{tabular}

Factors that are significantly different $(p \leq 0.05)$ between the two groups are in bold.

Results of tests of speed, jumping ability, shoulders strength, agility, abdominal strength, flexibility and endurance showed the advantage of boys in standing long jump and the Cooper test $(p \leq 0.05)$ and a high level of girls' trunk flexion $(p \leq 0.05)$. Elementary developmental parameters (height, weight and skinfold thickness) of girls are higher ( $p \leq 0.05)$. Another group of parameters in biological development that was measured were breathing indicators of lungs. The spirometric test indicated essential differences with dominance of girls $(p \leq 0.05)$. Lack of difference in the Tiffeneau index and in PEF between both sexes is an exception.

The analysis of correlation between individual parameters of motor development and respiratory indicators did not show many essential relationships (Table 2). The links refer to $\mathrm{MMEF}_{25 / 75}$ with reference to shoulders strength. In this case correlation has a positive value.

Table 2. The correlation coefficient between parameters of motor development and selected respiratory indicators in the group of boys

\begin{tabular}{|l|c|c|c|c|c|c|c|}
\hline Feature & Speed & $\begin{array}{c}\text { Jumping } \\
\text { ability }\end{array}$ & $\begin{array}{c}\text { Shoulder } \\
\text { strength }\end{array}$ & Agility & $\begin{array}{c}\text { Abdominal } \\
\text { strength }\end{array}$ & Flexibility & $\begin{array}{c}\text { Endur- } \\
\text { ance }\end{array}$ \\
\hline FVC & -0.05 & 0.07 & 0.08 & 0.08 & 0.01 & 0.12 & 0.02 \\
\hline FEV1 & -0.01 & 0.07 & 0.17 & 0.06 & 0.11 & 0.11 & 0.05 \\
\hline FEV1/FVC & 0.06 & 0.00 & 0.12 & -0.03 & 0.14 & -0.01 & 0.04 \\
\hline MMEF $25 / 75$ & 0.12 & 0.15 & 0.21 & 0.06 & 0.19 & -0.04 & 0.07 \\
\hline PEF & 0.13 & 0.19 & 0.19 & 0.10 & 0.14 & 0.18 & 0.08 \\
\hline
\end{tabular}

Values in bold are significant at $5 \%$ level

Considerably more relationships were discovered while examining other, besides the respiratory system, elements of body build (Table 3 ). Body height was negatively correlated with speed, shoulders strength and abdominal strength. More correlations were revealed with reference to body weight negatively correlated with speed, jumping ability, shoulders strength, abdominal 
strength and with endurance. However, the skinfold thickness is linked with speed, jumping ability, shoulders strength, agility and also with endurance. In all cases correlations were negatively correlated as well.

Table 3. The correlation coefficient between parameters of motor development and selected somatic features in the group of boys

\begin{tabular}{|l|c|c|c|c|c|c|c|}
\hline Feature & Speed & $\begin{array}{c}\text { Jumping } \\
\text { ability }\end{array}$ & $\begin{array}{c}\text { Shoulder } \\
\text { strength }\end{array}$ & Agility & $\begin{array}{c}\text { Abdominal } \\
\text { strength }\end{array}$ & Flexibility & $\begin{array}{c}\text { Endur- } \\
\text { ance }\end{array}$ \\
\hline Height & $\mathbf{0 . 8 6}$ & -0.12 & -0.27 & -0.04 & -0.25 & -0.45 & -0.08 \\
\hline Weight & -0.22 & -0.32 & -0.38 & -0.11 & -0.22 & 0.00 & -0.45 \\
\hline $\begin{array}{l}\text { Skinfol } \\
\text { thickness }\end{array}$ & -0.40 & -0.40 & -0.42 & -0.21 & -0.20 & -0.13 & -0.53 \\
\hline
\end{tabular}

Values in bold are significant at 5\% level

In the group of girls different correlations were observed: more links between respiratory parameters and motor features, and a smaller number in the scope of the remaining morphological features referring to motor elements (Table 4). All correlations of motor features with respiratory indicators are positive. The FVC indicator is correlated with flexibility similarly to the FEV1 indicator which, additionally, is correlated with shoulders strength. Apart from that, shoulders strength is also correlated with the Tiffeneau index. PEF indicator is correlated with abdominal strength and suppleness.

Table 4. The correlation coefficient between parameters of motor developmentand selected respiratory indicators in the group of girls

\begin{tabular}{|l|c|c|c|c|c|c|c|}
\hline Feature & Speed & $\begin{array}{c}\text { Jumping } \\
\text { ability }\end{array}$ & $\begin{array}{c}\text { Shoulder } \\
\text { strength }\end{array}$ & Agility & $\begin{array}{c}\text { Abdominal } \\
\text { strength }\end{array}$ & $\begin{array}{c}\text { Flexibility } \\
\text { Endur- } \\
\text { ance }\end{array}$ \\
\hline FVC & 0.16 & -0.07 & 0.14 & 0.07 & 0.13 & $\mathbf{0 . 2 1}$ & -0.02 \\
\hline FEV1 & 0.14 & -0.03 & $\mathbf{0 . 2 3}$ & 0.05 & 0.20 & $\mathbf{0 . 2 1}$ & 0.00 \\
\hline FEV1/FVC & -0.04 & 0.07 & $\mathbf{0 . 2 4}$ & -0.04 & 0.12 & 0.02 & 0.02 \\
\hline MMEF25/75 & 0.00 & 0.02 & 0.15 & -0.04 & 0.14 & 0.13 & -0.07 \\
\hline PEF & 0.18 & 0.17 & 0.15 & -0.05 & $\mathbf{0 . 2 2}$ & $\mathbf{0 . 2 6}$ & -0.09 \\
\hline
\end{tabular}

Values in bold are significant at $5 \%$ level

Correlations of motor indicators with the remaining somatic features taken into consideration in the research refer only to speed and jumping abilities, which are significantly connected with weight and skinfold thickness (Table 5).

Table 5. The correlation coefficient between parameters of motor development and selected somatic features in the group of girls

\begin{tabular}{|l|c|c|c|c|c|c|c|}
\hline Feature & Speed & $\begin{array}{c}\text { Jumping } \\
\text { ability }\end{array}$ & $\begin{array}{c}\text { Shoulder } \\
\text { strength }\end{array}$ & Agility & $\begin{array}{c}\text { Abdominal } \\
\text { strength }\end{array}$ & Flexibility & $\begin{array}{c}\text { Endur- } \\
\text { ance }\end{array}$ \\
\hline Height & -0.07 & 0.00 & -0.12 & -0.10 & -0.05 & 0.10 & -0.21 \\
\hline Weight & $\mathbf{- 0 . 2 5}$ & $-\mathbf{- 0 . 2 1}$ & -0.17 & -0.05 & -0.07 & 0.17 & -0.29 \\
\hline $\begin{array}{l}\text { Skinfold } \\
\text { thickness }\end{array}$ & $\mathbf{- 0 . 3 4}$ & $-\mathbf{- 0 . 3 8}$ & -0.17 & -0.20 & -0.01 & 0.12 & -0.40 \\
\hline
\end{tabular}

Values in bold are significant at 5\% level

The last column of Tables 2-5 referred to endurance measured by the Cooper test and its connections with the body build. In this case negative correlation of weight and skinfold with endurance was found in boys. In girls, however, apart from these two parameters, also body height is negatively correlated with physical capacity. 


\section{Discussion}

Sex differences in the height, weight and skinfold thickness showed higher values in girls, similarly as in Ambroży's [20] report for youths in this same age. Hormones produced by gonads stimulated gender differences in morphological development. In girls they are activated several months earlier than in boys. Age for female subjects allows observing these processes, specially faster bone in-growth and body mass, related with fat deposition. Characteristic among boys hormonally controlled development of skeleton and muscles has not been observed yet. The results seem to support Szopa's [21] and Żak's [22] analysis of obesity status among 12-year-old adolescents. Mean height (150 cm for boys and $157 \mathrm{~cm}$ for girls) and weight (43 kg for boys and $50 \mathrm{~kg}$ for girls) are similar to Rożek's [23] results: $150 \mathrm{~cm}$ for boys and $157 \mathrm{~cm}$ for girls, $43 \mathrm{~kg}$ for boys and $50 \mathrm{~kg}$ for girls.

Considering research on the relation between maximum ventilation of lungs and fitness [24,25], one should expect the existence of these relationships. The analysis of the material confirms generally known regularities that body composition (weight, fatty tissue) considerably influences the results of fitness tests $[3,4,5]$. Successes of competitors in endurance events (Cooper test), however, do not solely depend on a high value of oxygen limit and maximum ventilation. The authors' own research findings led to the same conclusion.

Forced vital capacity (2.93 I for boys and 3.13 I for girls) was slightly higher compared with Rożek's data [23] - 2.70 I for boys and girls. The FEV1/FVC ratio, also called the Tiffeneau index, was $89 \%$ for boys and $90 \%$ for girls confirming earlier values by Rożek [23] - 85\% for boys and $87 \%$ for girls, Lis [26] - 85\%, Kemper et al. [27] and Klimek et al. [28] - 88\%.

Selected and analysed parameters of the respiratory system are only partially correlated with chosen components of physical fitness. However, there is no correlation of these parameters with endurance both in boys and in girls. Although the Cooper test is an indirect method determining the peak oxygen uptake, close correlation of ventilation of lungs with $\mathrm{VO}_{2 \max }$ was not found in the research group. Since reports on connections between parameters of the respiratory system and physical fitness have not been explicitly explained so far, and they most often concerned training persons [12], it was hard to expect detecting such connections in a research group of young people, when the majority of them do not have any contact with physical activity in the training cycle. Shephard and Lavallée [9] considered a regular physical education curriculum (five hours of additional physical education per week) can enhance lung volumes in a group of 12-year-old adolescents. But Rożek's [23] analysis showed no correlation between selected lung parameters and jumping ability and shoulder strength.

Connections between individual motor abilities as well as physical capacity itself and the remaining somatic features are definitely closer, which with respect to physical capacity concerns both sexes, and in the case of physical fitness particularly refers to the male group. Thus these results confirm earlier information about essential links between body build and its fitness. Although many works claim weak correlation between the BMI level and such measures of positive health as physical capacity and motor skill, one should assume that relationships between fat deposition and physical fitness in the majority of cases are significant and are negatively correlated $[29,30]$.

\section{Conclusions}

Collected research findings led to some final conclusions.

1. Biological and motor measurements did not indicate essential differences of fitness components measured in points in thecase of speed, shoulders strength, agility and abdominal strength. Advantage of girls' flexibility and boys' jumping ability and endurance are observed. Girls' biological dominance is seen and this includes in particular skinfold thickness, but height and weight too.

2. In the matter of ventilation parameters no relations with physical capacity in both sexes was proved, probably because the tested group of subjects was examined with respect to PE classes and the majority of them did not have any contact with systematic training. It seems that in the case of young persons realizing physical activity only within compulsory school classes, the respiratory system and its parameters are a less important feature shaping physical 
capacity than e.g. body height and particularly body weight and often strongly connected with body weight thickness of fatty tissue. With reference to motor abilities connected with overall efficiency, few correlations with selected parameters of the respiratory system were found, yet more numerous amongst girls.

3. While numerous connections were determined with height, body weight and thickness of fatty tissue with reference to the same motor abilities in boys, lack of any correlations with these somatic features was noted only in suppleness. Amongst girls only speed and jumping ability were correlated with body weight and skinfold thickness. Although numerous reports show that physical capacity is an important determinant of physical fitness, respiratory parameters in a view of other features of the body build are more closely correlated with fitness components than with physical capacity.

\section{References}

1. Jagiello W, Kalina R, Tkaczuk W. Development of strength abilities in children and youth. Biol Sport. 2004;21:352-366.

2. Olszanecka-Glinianowicz M, Zahorska-Markiewicz B, Kocełak P, Plewa M, Janowska J. The effect of weight loss on serum concentrations of nitric oxide induced by short-term exercise in obese women. Biol Sport. 2009;26:173-182.

3. Beunen G, Malina R, Ostyn M, Renson R, Simons J, Van Gerven D. Fatness, growth and motor fitness of Belgian boys. Hum Biol. 1983;3:599-613.

4. Malina R, Beunen G, Classens A, et al. Fatness and physical fitness of girls 7 to 17 years. Obes Res. 1995;3:221-231.

5. Radsepp L, Jurimae T. Physical activity, aerobic fitness and fatness in preadolescent children. Sport Med Training Rehab. 1998;8:123-131.

6. Graf C, Koch B, Kretschmann-Kandel E, et al. Correlation between BMI, leisure habits and motor abilities in childhood (CHILT-Project). Int J Obes. 2004;28:22-26.

7. Monyeki M, Koppes L, Kemper H, et al. Body composition and physical fitness of undernourished South African rural primary school children. Eur J Clin Nutr. 2005;59:877-883.

8. Mercier J, Varray A, Ramonatxo M, Mercier B, Préfaut C. Influence of anthropometric characteristics on changes in maximal exercise ventilation and breathing pattern during growth in boys. Eur J Appl Physiol Occup Physiol. 1991;63:235-241.

9. Shephard R, Lavallée H. Effects of enhanced physical education on lung volumes of primary school children. J Sports Med Phys Fitness. 1996;36:186-194.

10. Twisk J, Staal B, Brinkman M, Kemper H, van Mechelen W. Tracking of lung function parameters and the longitudinal relationship with lifestyle. Eur Respir J. 1998;12:627-634.

11. Zverev Y, Gondwe M. Ventilatory capacity indices in Malawian children. East Afr Med J. 2001;78:14-18.

12. Doherty M, Dimitriou L. Comparison of lung volume in Greek Swimmers, land based athletes, and sedentary controls using allometric scaling. Br J Sport Med. 1997;31:337-341.

13. Cheng Y, Macera C, Addy C, Sy F, Wieland D, Blair S. Effect of physical activity on exercises tests and respiratory function. Br J Sport Med. 2003;37:521-528.

14. Lemaitre F, Bedu M, Coudert J. Pulmonary function in children and adult scuba divers: a longitudinal study. Pediatr Exerc Sci. 2004;16:378-390.

15. Rozek K, Slawinska T, Ignasiak Z, Domaradzki J. The relationship between adiposity and lung ventilation parameters and physical efficiency in the youth from industrial regions. Pol $\mathrm{J}$ Environ Stud. 2006;15(2B):678-681.

16. Schunemann H, Dorn J, Grant B. Pulmonary function is a long term predictor of mortality in the general population: 29-years follow-up of the Buffalo Health Study. Chest. 2000;118:656-664.

17. Lohman TG. The use of skinfolds to estimate body fatness on children and youth. JOPERD. 1987;58(9):98-102.

18. Cooper KH. The Aerobics Way. New York: Bantam Books; 1981.

19. Trzesniowski R, Pilicz S. Tabele sprawnosci fizycznej młodziezy w wieku od 7-19 lat [Tables of physical fitness of youth aged 7-19]. Warszawa: AWF; 1989. Polish.

20. Ambrozy T. Ocena dymorfizmu plciowego w zakresie cech somatycznych oraz sprawnosci motorycznej dzieci i młodziezy z wybranych regionow wojewodztwa krakowskiego [An assessment of sex dimorphism in somatic features and motor fitness of children and youth from selected regions of the Krakow province. In. Socha T, ed. Problemy dymorfizmu plciowego w sporcie [Issues of sex dimorphism in sport]. Katowice: AWF; 2002, 92-101. Polish.

21. Szopa J. Zmiennosc ontogenetyczna, zroznicowanie srodowiskowe oraz genetyczne uwarunkowania rozwoju komponentow ciala w populacji wielkomiejskiej w wieku 7-61 lat [Ontogenetic variability, envi- 
ronmental diversity and genetic determinants of the development of body components in an urban population aged 7-61]. Monograph No 22. Krakow: AWF; 1985. Polish.

22. Zak S. Zdolnosci kondycyjne i koordynacyjne dzieci i młodziezy w populacji wielkomiejskiej na tle wybranych uwarunkowan somatycznych i aktywnosci ruchowej [Condition and coordination skills of children and youth in an urban population compared to selected somatic determinants and physical activity]. Monograph No 43. Krakow: AWF; 1991. Polish.

23. Rozek K. Wybrane parametry wentylacyjne pluc w aspekcie poziomu zdolnosci motorycznych dzieci I młodziezy [Selected ventilator parameters of lungs in the aspect of the level of motor skills in children and youth]. Studia i Monografie [Studies and Monographs] No 84. Wrocław: AWF; 2006. Polish.

24. Wang X, Dockery D, Wypij D, Fay M, Ferris B Jr. Pulmonary function between 6 and 18 years of age. Pediatr Pulmonol. 1993;15:75-88.

25. Nair R, Kesavachandran C, Sanil R, Sreekumar R, Shashidhar S. Prediction equation for lung functions in South Indian children. Indian J Physiol Pharmacol. 1997;41(4):390-396.

26. Lis G, Haluszka J, Wilim G. Wartosc krzywej przeplyw-objetosc u dzieci zdrowych z Krakowa [The value of the flow-volume curve in healthy children from Krakow]. Pneumonol Alergol Pol. 1993;61(1-2):11-17. Polish.

27. Kemper H, Verschuur R. Maximal aerobic Power in 13- and 14-years-old teenagers in relation to biologic age. Int J Sports Med. 1981;2:97-100.

28. Klimek A, Cempla J. Zmiany parametrow fizjologicznych charakteryzujacych progi metaboliczne i maksymalne obciazenie wysilkowe u chłopcow w okresie dojrzewania [Changes in physiological parameters characterising metabolic thresholds and maximal loads in adolescent boys]. Antropomotoryka. 1997;16:127-145. Polish.

29. Tokmakidis S, Kasambalis A, Christodoulos A. Fitness levels of Greek primary schoolchildren in relationship to overweight and obesity. Eur J Pediatr. 2006;165:867-874.

30. Boddy L, Hackett A, Stratton G. Changes in BMI and prevalence of obesity and overweight in children in Liverpool, 1998-2006. Perspect Public Heal. 2009;129:127-131. 